\title{
Synthesis, Characterization and Analysis of Leishmanicide Ability of the Compound $\left[\mathrm{Ru}(\mathrm{Cl})_{3}\left(\mathrm{H}_{2} \mathrm{O}\right)_{2}\right.$ (gly)]
}

\author{
Marcio Adriano S. Chagas ${ }^{1 *}$, Anderson Dourado Galvão ${ }^{1}$, Fabricio Tarso de Moraes ${ }^{1}$, \\ Andressa Teixeira Barros Nunes Ribeiro', Adriano Buzutti de Siqueira ${ }^{1}$, \\ Isabel Cristina Cabral de Assis Salama ${ }^{1}$, Wagner Welber Arrais-Silva ${ }^{2}$, \\ Katia Meirelles Duarte de Sousa' ${ }^{1}$, Claudia Cristina de Sousa Pereira1, \\ Wagner Batista dos Santos ${ }^{1 \#}$
}

${ }^{1}$ Federal University of Mato Grosso, Barra do Garças, Brazil
${ }^{2}$ Federal University of Sergipe, São Cristovão, Brazil
Email: ${ }^{*}$ marciochagas_quimica@hotmail.com, " wbsantos@ufmt.br

How to cite this paper: Chagas, M.A.S., Galvão, A.D., de Moraes, F.T., Ribeiro, A.T.B.N., de Siqueira, A.B., de Assis Salama, I.C.C., Arrais-Silva, W.W., de Sousa, K.M.D., de Sousa Pereira, C.C. and dos Santos, W.B. (2017) Synthesis, Characterization and Analysis of Leishmanicide Ability of the Compound $\left[\mathrm{Ru}(\mathrm{Cl})_{3}\left(\mathrm{H}_{2} \mathrm{O}\right)_{2}(\right.$ gly $\left.)\right]$. Open Journal of Inorganic Chemistry, 7, 89-101.

https://doi.org/10.4236/ojic.2017.74006

Received: August 29, 2017

Accepted: October 23, 2017

Published: October 26, 2017

Copyright $\odot 2017$ by authors and Scientific Research Publishing Inc. This work is licensed under the Creative Commons Attribution International License (CC BY 4.0).

http://creativecommons.org/licenses/by/4.0/

\begin{abstract}
Studies of coordinated compounds containing ruthenium $\left(\mathrm{Ru}^{2+}\right.$ and $\left.\mathrm{Ru}^{3+}\right)$ have shown very effective in vitro results for the treatment of cancer and neglected diseases such as leishmaniasis. In this paper, we present the synthesis of the compound $\left[\mathrm{Ru}(\mathrm{Cl})_{3}\left(\mathrm{H}_{2} \mathrm{O}\right)_{2}(\mathrm{gly})\right]$, which was characterized by spectroscopic (Ultraviolet-visibleand infrared) and thermal analysis (Thermogravimetry/Derived Thermogravimetry and Thermogravimetry/Differential Thermal Analysis). The analysis of the compound in the Ultraviolet-visibleregion showed a $290 \mathrm{~nm}$ band $\lambda_{\max }\left(\varepsilon=1.685 \times 10^{3} \mathrm{~L} \cdot \mathrm{cm}^{-1} \cdot \mathrm{mol}^{-1}\right)$, attributed to the ligand metal charge transfer (LMCT). The spectroscopy (IR) showed major vibrational bands at $\delta_{\mathrm{a}}\left(-\mathrm{COO}^{-}\right) 1664 \mathrm{~cm}^{-1}, \delta_{\mathrm{s}}\left(-\mathrm{COO}^{-}\right) 1388 \mathrm{~cm}^{-1}, \delta_{\mathrm{s}}\left(\mathrm{NH}_{3}^{+}\right)$ $1571 \mathrm{~cm}^{-1}$ and $\delta_{\mathrm{s}}(\mathrm{CCN}) 889 \mathrm{~cm}^{-1}$. The thermal analysis by TG/DTG and TG-DTA indicated that the complex has five consecutive stages of decomposition: at $115^{\circ} \mathrm{C}(\mathrm{TG}=12.18 \%$; Calculated $=11.32 \%) \mathrm{H}_{2} \mathrm{O}$ (coordinating water), exothermic peaks at $230^{\circ} \mathrm{C}, 307^{\circ} \mathrm{C}, 440^{\circ} \mathrm{C}$ and $463^{\circ} \mathrm{C}$ due to oxidative decomposition of glycine, followed by the formation of $\mathrm{RuClO}$ residue at $665^{\circ} \mathrm{C}(\mathrm{TG}=41.11 \%$; Calculated $=40.81 \%)$. The thermal characterization suggested the stoichiometry of the complex $\left[\mathrm{RuCl}_{3}\left(\mathrm{H}_{2} \mathrm{O}\right)_{2}(\right.$ gly $\left.)\right]$. The antileishmanial capacity of this compound was also evaluated and the results indicated a $31 \%$ decrease in the parasitic infection of macrophages and a 1.5 to 3 fold reduction in the number of parasites per cell after treatment with 100 $\mu \mathrm{g} / \mathrm{mL}$ of the complex. These results support the possible use of this compound as a therapeutic alternative against medical and veterinary parasites.
\end{abstract}




\section{Keywords}

Ruthenium, Glycine, Spectroscopy, Infrared TG/DTG and TG/DTA, Amino Acid

\section{Introduction}

Metals and inorganic compounds have been used in medical therapies since the sixteenth century (Sadler, 1991; Abdel-Rahman, 2013; Abdel-Rahman, 2016) [1] [2] [3]. In 1969, the antitumor activity of metallic complexes containing cisplatin was discovered (Katsaros and Anagnostopoulou 2002) [4] enabling the development of new antitumor drugs such as complexes involving organic metals and/or inorganic platinum, ruthenium and rhodium (PAULA et al. 2005; Waxman and Anderson 2001) [5] [6]. Gallori and colleagues suggest that compounds containing ruthenium can bind to the DNA molecule, and that this interaction can alter the cell cycle, causing cell death through mechanisms such as apoptosis (Gallori et al. 2000) [7]. Evidence also suggests that several ruthenium complexes interact with specific proteins. One such application is the use of red ruthenium, which is traditionally used as a cytological stain for electron microscopy. In this case, binding of the compound occurs in the anionic sites of calcium-binding proteins (Clarke 2003; Suriano et al. 2005) [8] [9]. It was observed that several compound $\mathrm{Ru}^{2+}$ and $\mathrm{Ru}^{3+}$ amine ligands tend to interact selectively the carbonyl and imino sites of biomolecules that do not protonam at neutral $\mathrm{pH}$. This leaves the pairs of electrons (of Nitrogen) available to coordinate bond with metal ions. Accordingly, ruthenium complexes often bind to proteins and imidazole nitrogen purine nucleotide (Clarke et al. 1978; Gupta et al. 2011) [10] [11]. Vilanova-Costa investigated the action of the compound cis- $\left[\mathrm{RuCl}_{2}\left(\mathrm{NH}_{3}\right)_{4}\right]$, which showed antitumor activity in vitro on human tumor cell lines and in vivo on a tumor mouse strain (Sarcoma-180 (S-180) (Pereira et al. 2014; Vilanova-Costa et al. 2014; Vilanova-Costa et al. 2015) [12] [13] [14]. However, despite its pharmacological potential, the activity of ruthenium against leishmaniasis has not been extensively studied, even though the formation of granulomas that is characteristic of chronic leishmaniasis is similar to that observed in solid tumors (Arrais-Silva et al. 2006) [15]. Works that demonstrate the action of ruthenium against $L$. Mexicana promastigotes indicate the possible therapeutic action of the compounds of ruthenium (Navarro et al. 2006) [16]. Using in vitro models, Navarro (Navarro et al. 2006) [16] also demonstrated that some compounds containing the metal ruthenium decrease the L. Mexicana promastigotes forms by between $36 \%$ and $49 \%$ after treatment for 48 hours at a dose of $10 \mu \mathrm{M}$, with loss of movement, fission of parasitic forms and vacuolation abundant in the host cell. The present study reports the synthesis of $\left[\mathrm{Ru}(\mathrm{Cl})_{3}\left(\mathrm{H}_{2} \mathrm{O}\right)_{2}(\mathrm{gly})\right]$ and its characterization by UV-VIS analysis, IR, TG/DTG and TG/DTA. A biological analysis of the effectiveness of the ruthenium compound in treating an experimental 
model of leishmaniasis was also carried out.

\section{Experimental}

Materials. For synthesis of analytical grade complex compounds, $\mathrm{RuCl}_{3} \cdot 3 \mathrm{H}_{2} \mathrm{O}$ and glycine $\left(\mathrm{NH}_{2} \mathrm{CH}_{2} \mathrm{COOH}\right)$ were used. Distilled water, ethyl ether $\left(\mathrm{C}_{4} \mathrm{H}_{10} \mathrm{O}\right)$ and absolute alcohol $\left(\mathrm{C}_{2} \mathrm{H}_{6} \mathrm{O}\right)$ were used as solvents.

Synthesis: For the synthesis of compound $\left[\mathrm{Ru}(\mathrm{Cl})_{3}\left(\mathrm{H}_{2} \mathrm{O}\right)_{2}(\right.$ gly $\left.)\right], 300.0 \mathrm{mg}$ ( $1.440 \mathrm{mmol}$ ) of $\mathrm{RuCl}_{3} \cdot 3 \mathrm{H}_{2} \mathrm{O}$ was solubilized in $9.0 \mathrm{~mL}$ of distilled water, then $1000 \mathrm{mg}$ (13.32 mmol) of glycine was added to the mixture under constant stirring, protected from light. After solubilization, the solution was allowed to reflux for 4 hours. The solution was held under ambient cold for 24 hours for precipitation. The precipitates were then filtered, washed with ethanol, ether and dried under reduced pressure. The solution was cooled again to obtain a higher yield of the precipitate. The solid was again washed with ethanol, ether and dried under reduced pressure.

Cell culture and parasites: Primary mouse macrophages were obtained from normal BALB/c mice by peritoneal lavage (Barbiéri et al. 1993; Giorgio et al. 1998) [17] [18]. Leishmania Amazonensis (MHOM/BR/73/M2269) amastigote forms were isolated from active skin lesions of $\mathrm{BALB} / \mathrm{c}$ mice as described previously (Barbiéri et al. 1993) [17]. The parasites were suspended in RPMI 1640 medium and used immediately after isolation.

Macrophage infection and assessment of intracellular parasites: Peritoneal macrophages were infected with $L$. Amazonensisamastigotes (5:1 parasites/host cell) for $1 \mathrm{~h}$, as previously described (Colhone et al. 2004) [19]. After the interaction period, the cultures were washed to remove extracellular parasites and fresh medium was added to the cell culture and incubated at $35^{\circ} \mathrm{C}, 5 \%$ of $\mathrm{CO}_{2}$ for $24 \mathrm{~h}$, as previously described (Degrossoli and Giorgio 2007) [20]. Alternatively, different concentrations of $\mathrm{RuCl}_{3} \cdot 3 \mathrm{H}_{2} \mathrm{O}$ and glycine were added to culture of infected cells. Intracellular parasite destruction was assessed by morphological examination. Briefly, in order to evaluate the percentage of infected macrophages and the number of amastigotes per macrophage, cells cultured on coverslips were stained with Giemsa 0.6\% (Giorgio et al. 1998) [18]. Intracellular amastigotes, which are exclusively localized in parasitophorous vacuoles (Chang 1980) [21], were examined microscopically at a magnification of 1000x. About 600 cells were counted per triplicate coverslip (Linares et al. 2000) [22].

Cytotoxicity assay: The cytotoxicity of ruthenium to macrophages was tested using the MTT viability assay, after incubation of peritoneal-derived macrophages with 50 to $400 \mu \mathrm{g} / \mathrm{mL}$ of ruthenium for 24 hours. The formation of formazan was measured by adding $0.5 \mathrm{mg} / \mathrm{mL}$ of 3-(4,5-dimethylthiazol-2-yl)-2, 5-diphenyltetrazolium bromide (MTT; Molecular Probes, Eugene, OR, USA) and incubating the cultures at $37^{\circ} \mathrm{C}$ in the dark. After $4 \mathrm{~h}$ the medium was removed, $200 \mathrm{uL}$ of DMSO (dimethyl sulphoxide) was added per well and the absorbance was measured using an ELISA reader at $540 \mathrm{~nm}$ (LabsystemsMul- 
tiskan). As a negative control, cells were also incubated with the highest concentration of DMSO used for ruthenium solubilization (0.01\%).

Data analysis: The results were expressed as mean \pm standard deviation (SD). To compare the average values of the parameters, analysis of variance (ANOVA) followed by multiple comparisons of Tukey test were used, with a statistical significance threshold of $5 \%(\mathrm{p}<0.05)$. The BioEstat version 5.0 software was used for all analyses (Ayres et al. 2007) [23].

Instrumental Methods. For analysis of UV-VIS and IR for the compound of ruthenium equipment of the company Perkin Elmer ${ }^{\circledR}$, model Lambda 25 UV-VIS analysis for the region of visible and UV-Spectrum-100 for the mid-infrared region were used. For the analysis of TG/DTG and TG-DTA, $6.6204 \mathrm{mg}$ of the compound $\left[\mathrm{Ru}(\mathrm{Cl})_{3}\left(\mathrm{H}_{2} \mathrm{O}\right)_{2}\right.$ gly] was placed in aa-alumina crucible and $90 \mathrm{uL}$ of the sample was heated to $800^{\circ} \mathrm{C}$ at a heating rate of $20^{\circ} \mathrm{C} / \mathrm{min}$ under an atmosphere of dry air a flow rate of $100 \mathrm{~mL} / \mathrm{min}$; the SDT $2960 \mathrm{TA}$ Instruments ${ }^{\circledast}$ equipment was used for this analysis.

\section{Results and Discussion}

Ultraviolet visible analysis. Figure 1 shows the UV-Vis spectrum of the compound $\left[\mathrm{Ru}(\mathrm{Cl})_{3}\left(\mathrm{H}_{2} \mathrm{O}\right)_{2}(\mathrm{gly})\right]$ in water indicating the band $290 \mathrm{~nm}$. The literature shows that ruthenium-glycine compounds exhibit absorption in the 290 $\mathrm{nm}$ region, little intense, as characterized as LMCT-type interactions (Load Transfer Ligand Metal) between the oxygen of the carboxyl group (glycine) and metallic ion (ruthenium) (Yeh and Taube 1980) [24]. the band found in the ultraviolet region at $230 \mathrm{~nm}$, can be attributed to internal transitions of the ligand (IL), and were very similar in intensity to electronic transitions $\pi-\pi^{\star}$ free ligand (Bento and Tfouni 1988) [25].

Analysis in infrared medium region: Table 1 highlights the values of the vi-

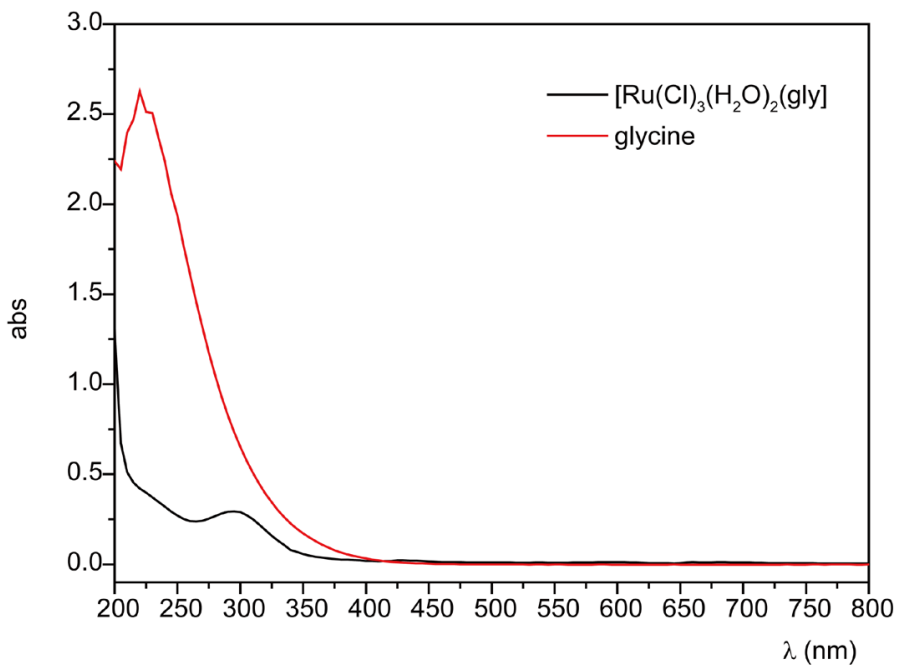

Figure 1. UV-vis spectrum of compound $\left[\mathrm{Ru}(\mathrm{Cl})_{3}\left(\mathrm{H}_{2} \mathrm{O}\right)_{2}(\right.$ gly) $] 2 \times 10^{-4}$ $\mathrm{mol} \cdot \mathrm{L}^{-1}\left(290 \mathrm{~nm} \varepsilon=1685 \mathrm{~L} \cdot \mathrm{cm}^{-1} \cdot \mathrm{mol}^{-1}\right)$ and glycine $(194 \mathrm{~nm} \varepsilon=13129$ $\left.\mathrm{L} \cdot \mathrm{cm}^{-1} \cdot \mathrm{mol}^{-1}\right)$. 
Table 1. IR experimental for groups identified in the analyses.

\begin{tabular}{ccc}
\hline Glycine $\left(\mathrm{cm}^{-1}\right)$ & {$\left[\mathrm{Ru}(\mathrm{Cl})_{3}\left(\mathrm{H}_{2} \mathrm{O}\right)_{2}(\mathrm{gly})\right]\left(\mathrm{cm}^{-1}\right)$} & Bands assignments \\
\hline 3166 & 3093 & $v_{\mathrm{s}}(\mathrm{N}-\mathrm{H})$ \\
$3118-2875$ & $3035-2823$ & $v_{\mathrm{a}}(\mathrm{N}-\mathrm{H})+v_{\mathrm{sh}}(\mathrm{C}-\mathrm{H})$ \\
2930 & 2869 & $v\left(\mathrm{CH}_{2}\right)$ \\
2120 & 2167 & $\delta_{\mathrm{sc}}\left(\mathrm{CH}_{2}\right)$ \\
1603 & 1664 & $\delta_{\mathrm{a}}\left(\mathrm{COO}^{-}\right)$ \\
1408 & 1388 & $\delta_{\mathrm{s}}\left(\mathrm{COO}^{-}\right)$ \\
1584 & 1571 & $\delta\left(\mathrm{NH}_{3}^{+}\right)$ \\
1525 & 1490 & $\delta_{\mathrm{s}}\left(\mathrm{NH}_{3}^{+}\right)$ \\
1436 & 1441 & $\delta\left(\mathrm{CH}_{2}\right)$ \\
1332 & $1334-1322$ & $\rho_{\mathrm{w}}\left(\mathrm{CH}_{2}\right)$ \\
$1130-1110$ & $1155-1110$ & $\rho_{\mathrm{r}}\left(\mathrm{NH}_{3}^{+}\right)$ \\
1030 & 1043 & $v(\mathrm{C}-\mathrm{N})+v(\mathrm{C}-\mathrm{C})$ \\
910 & 927 & $\rho_{\mathrm{r}}\left(\mathrm{CH}_{2}\right)$ \\
892 & 889 & $v\left(\mathrm{CCN}^{2}\right)$ \\
694 & 684 & $\rho_{\mathrm{w}}\left(\mathrm{COO}^{-}\right)$ \\
603 & 607 & $\delta\left(\mathrm{COO}^{-}\right)$ \\
\hline
\end{tabular}

$v_{\mathrm{a}}$ : antisymmetrical stretching, $v_{\mathrm{s}}$ : symmetrical stretching, $\nu_{\text {sh }}$ : sholder stretching, $\delta_{\mathrm{a}}$ : asymmetric bending, $\delta_{\mathrm{s}}$ : symmetrical bending, $\rho_{\mathrm{w}}$ : wagging, $\rho_{\mathrm{r}}$ : rocking.

brational groups and their respective wave numbers, when comparing the experimental vibrational spectra of free glycine and synthesized $\left[\mathrm{Ru}(\mathrm{Cl})_{3}\left(\mathrm{H}_{2} \mathrm{O}\right)_{2}(\right.$ gly $\left.)\right]$.

The analysis of vibrational modes in the IR spectrum of glycine ligand, the carboxylate ion $\left(\mathrm{COO}^{-}\right)$shows a peak at $1664 \mathrm{~cm}^{-1}$, indicating their ionized form. The literature shows that compounds with the glycine ligand with bidentate characteristics decrease significantly the distance between the symmetric and asymmetric vibrational modes of the carboxylate ion. However, the increase in value of the distance between the vibrational modes symmetric and asymmetric carboxylate ion indicates that this group will form a monodentate connection with the metallic center (Kitamura et al. 2014; NAKAMOTO 1978) [26] [27]. When analyzing the data obtained for the compound $\left[\mathrm{Ru}(\mathrm{Cl})_{3}\left(\mathrm{H}_{2} \mathrm{O}\right)_{2}(\mathrm{gly})\right]$, when compared to the free ligand, we observed an increase in the difference between the symmetric and asymmetric displacement of the carboxylate ion, which indicates the formation of a monodentate connection between the carboxylate ion (glycine) and $\mathrm{Ru}^{3+}$ metal (Figure 2).

The data also show the presence of peaks relating to the bending group $\left(\mathrm{NH}_{3}^{+}\right)$in $\delta_{\delta}\left(\mathrm{NH}_{3}^{+}\right) 1571 \mathrm{~cm}^{-1}$ and $\delta_{\sigma}\left(\mathrm{NH}_{3}^{+}\right) 1490 \mathrm{~cm}^{-1}$ indicating the zwitterionic state of the glycine present in the complex. The displacement observed in the symmetric stretch of the -C-N group, in the compound $\left[\mathrm{Ru}(\mathrm{Cl})_{3}\left(\mathrm{H}_{2} \mathrm{O}\right)_{2}(\mathrm{gly})\right]$ compared to the free ligand (glycine), did not change significantly, $v_{\mathrm{s}}(-\mathrm{C}-\mathrm{N})_{\text {free ligand }}$ 


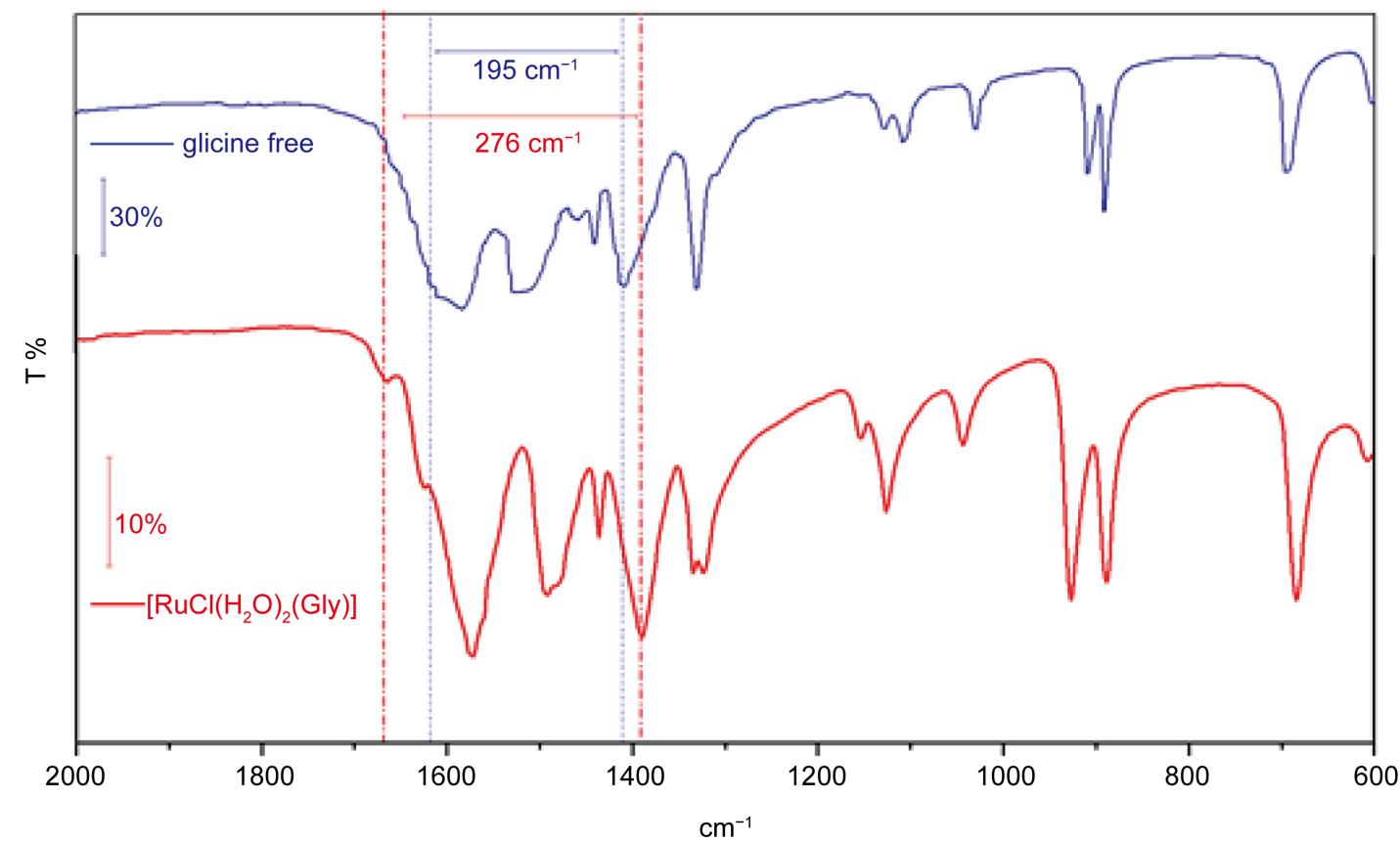

Figure 2. Variation of the group $\Delta\left(v_{\mathrm{a}} \mathrm{COO}^{-}-v_{\mathrm{s}} \mathrm{COO}^{-}\right)$, compound Glycine and complex $\left[\mathrm{Ru}(\mathrm{Cl})_{3}\left(\mathrm{H}_{2} \mathrm{O}\right)_{2}(\mathrm{gly})\right]$.

$892 \mathrm{~cm}^{-1}$ and $v_{\mathrm{s}}(-\mathrm{C}-\mathrm{N})_{\text {compound }} 889 \mathrm{~cm}^{-1}$. Vibrations related to bending and twisting group $\left(\mathrm{CH}_{2}\right)$ glycine in the complex suffered small variations in the region of $\delta\left(\mathrm{CH}_{2}\right) 1436 \mathrm{~cm}^{-1}$ and $\rho_{\omega}\left(\mathrm{CH}_{2}\right) 1334$ to $1322 \mathrm{~cm}^{-1}$ as compared to free glycine. Specifically, in the regions $v\left(\mathrm{CH}_{2}\right) 2869 \mathrm{~cm}^{-1}$ and $\delta_{\sigma \chi}\left(\mathrm{CH}_{2}\right) 2167 \mathrm{~cm}^{-1}$, it was possible to observe significant vibrational changes in relation to the free ligand, which may be attributed to intermolecular interaction between the $\mathrm{NH}_{3}^{+}$ and $\mathrm{COO}^{-}$groups.

TG/DTG and TG/DTA curves: The TG/DTG and TG/DTA curves shown in Figure 3 demonstrate the thermal decomposition of the complex in five consecutive steps. The first stage indicates the output of the ligand $\mathrm{H}_{2} \mathrm{O}\left(\mathrm{TG}_{\text {(experimental) }}=\right.$ $12.18 \% ; \mathrm{TG}_{\text {(theoretical) }}=11.32 \%$ ) with an endothermic peak at $115^{\circ} \mathrm{C}$. Studies with compounds of ruthenium complexed to ligands water, amine and glycine were obtained results similar to those observed in this work as the output water temperature ligand (Kohata et al. 1985) [28]. The following steps indicate thermal decomposition to $490^{\circ} \mathrm{C}$ with formation of the residue $\mathrm{RuClO}$. ( $\mathrm{TG}_{\text {(experimental) }}=$ $41.11 \%$; $\mathrm{TG}_{\text {(theoretical) }}=40.81 \%$ ). The last four steps are characterized by exothermic peaks at $230^{\circ} \mathrm{C}, 307^{\circ} \mathrm{C}, 440^{\circ} \mathrm{C}$ and $463^{\circ} \mathrm{C}$ due to oxidative decomposition of glycine monoxide and carbon dioxide.

Based on data obtained by infrared and thermal analysis, we propose a specific structure for the complex $\left[\mathrm{Ru}(\mathrm{Cl})_{3}\left(\mathrm{H}_{2} \mathrm{O}\right)_{2}(\right.$ gly $\left.)\right]$, as shown in Figure 4 .

Effect of ruthenium and glycine compound treatment cell viability

In order to analyze the effects of the ruthenium-glycine compound in an experimental model of leishmaniasis, cytotoxicity on the infection of macrophages had their effects analyzed. Cell viability was assessed using the MTT assay. The negative control cells (CLT) showed $100 \%$ cell viability. No cell toxicity was ob- 


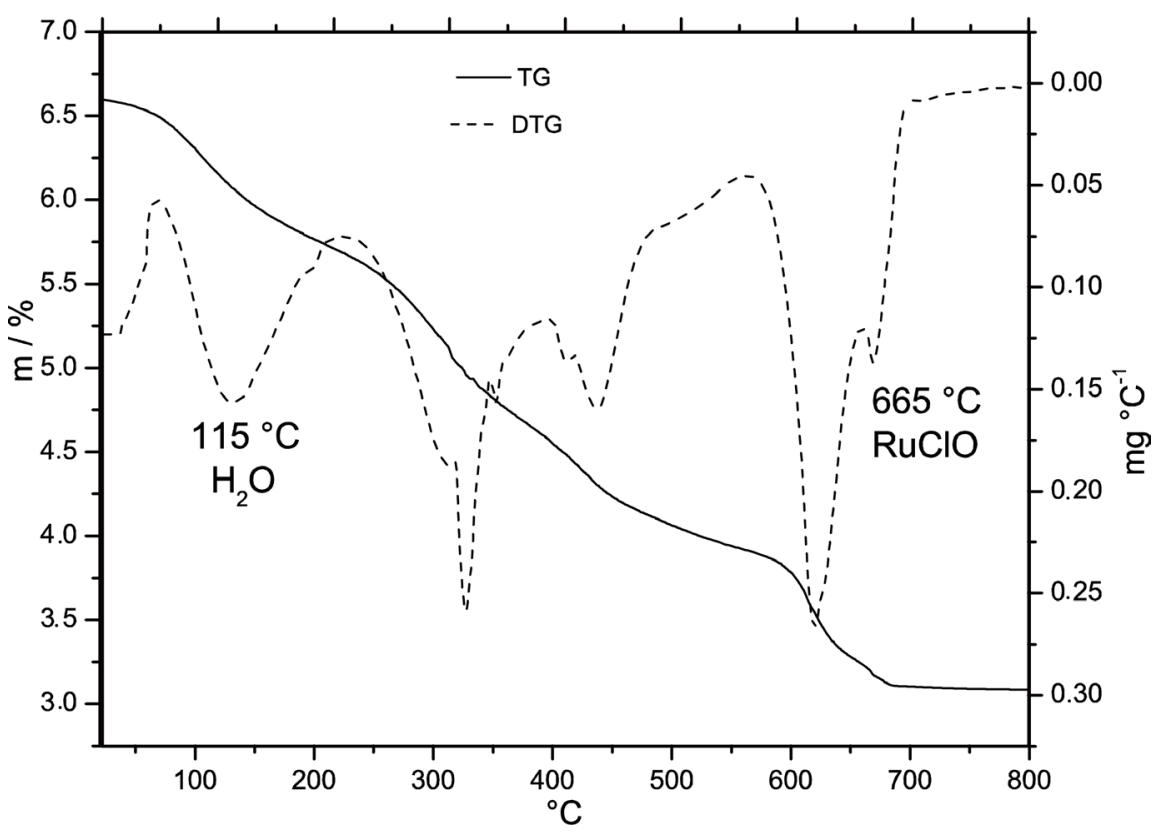

(a)

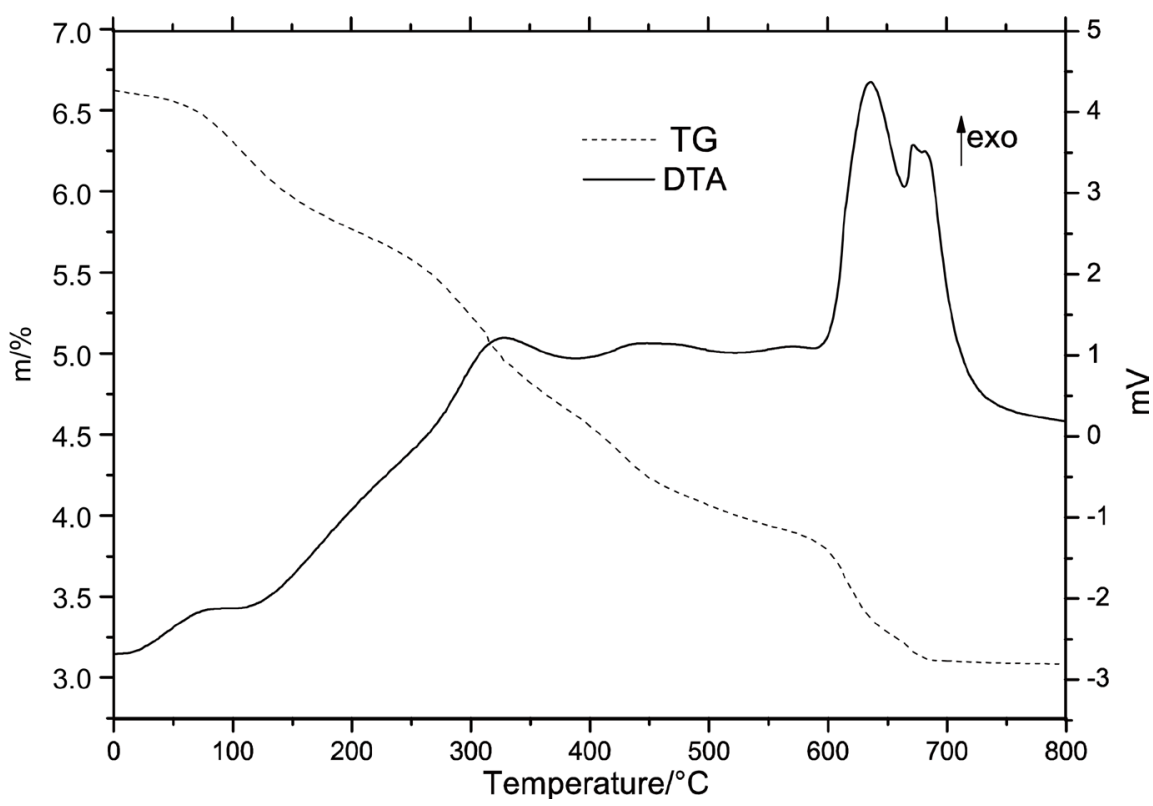

(b)

Figure 3. (a) TG/DTG curve; (b) TG-DTA curve. Compound: $\left[\mathrm{Ru}(\mathrm{Cl})_{3}\left(\mathrm{H}_{2} \mathrm{O}\right)_{2}(\right.$ gly)].

served for the ruthenium compound at doses between 50 and $400 \mu \mathrm{g} / \mathrm{mL}$ (Figure 5).

Effect of $\left[\mathrm{Ru}(\mathrm{Cl})_{3}\left(\mathrm{H}_{2} \mathrm{O}\right)_{2}(\mathrm{Gly})\right]$ compound and free glycine ligand in experimental infection of murine macrophages infected with Leishmaniaamazonensis.

Two controls (untreated cells and cells treated with DMSO) were used in this analysis. As expected, these controls showed no significant changes in cell infection percentages. 


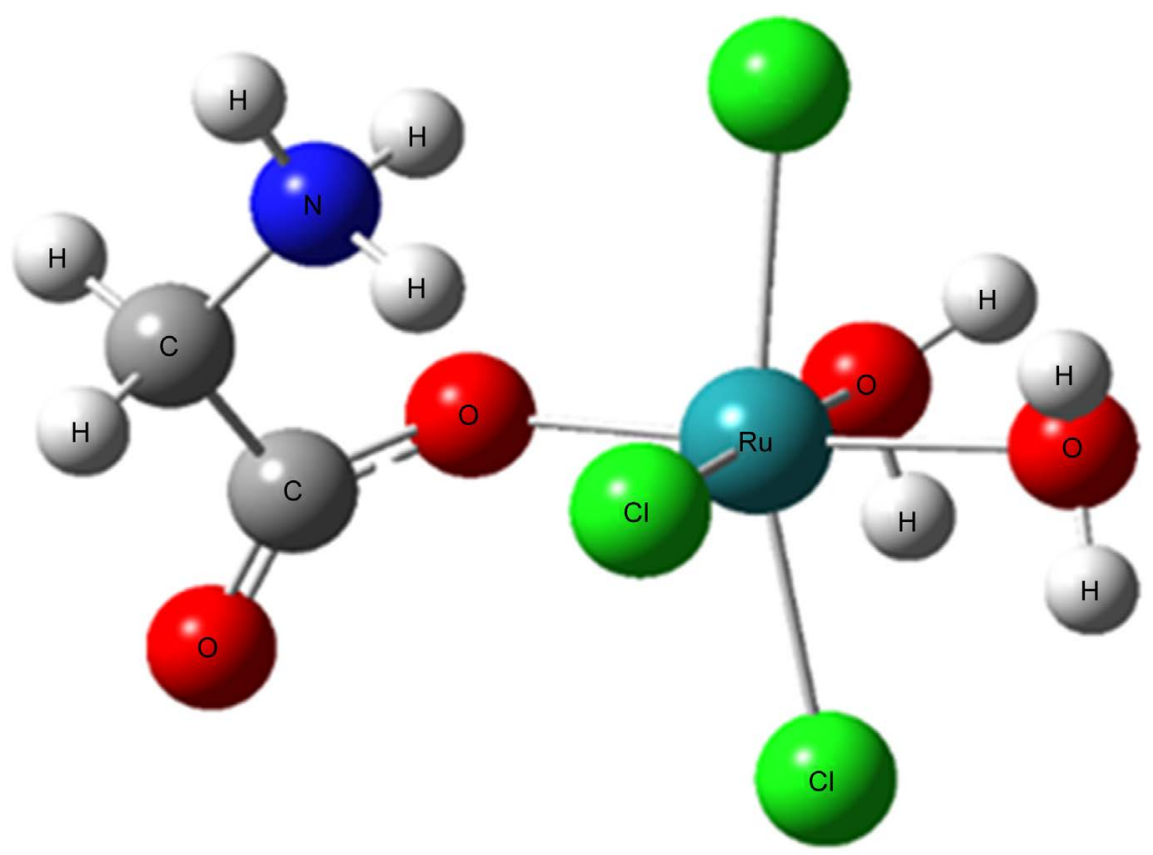

Figure 4. Structural representation for the compound $\mathrm{Ru}(\mathrm{Cl})_{3}\left(\mathrm{H}_{2} \mathrm{O}\right)_{2}(\mathrm{gly})$ ]. Image obtained by GaussView 5.0 program.

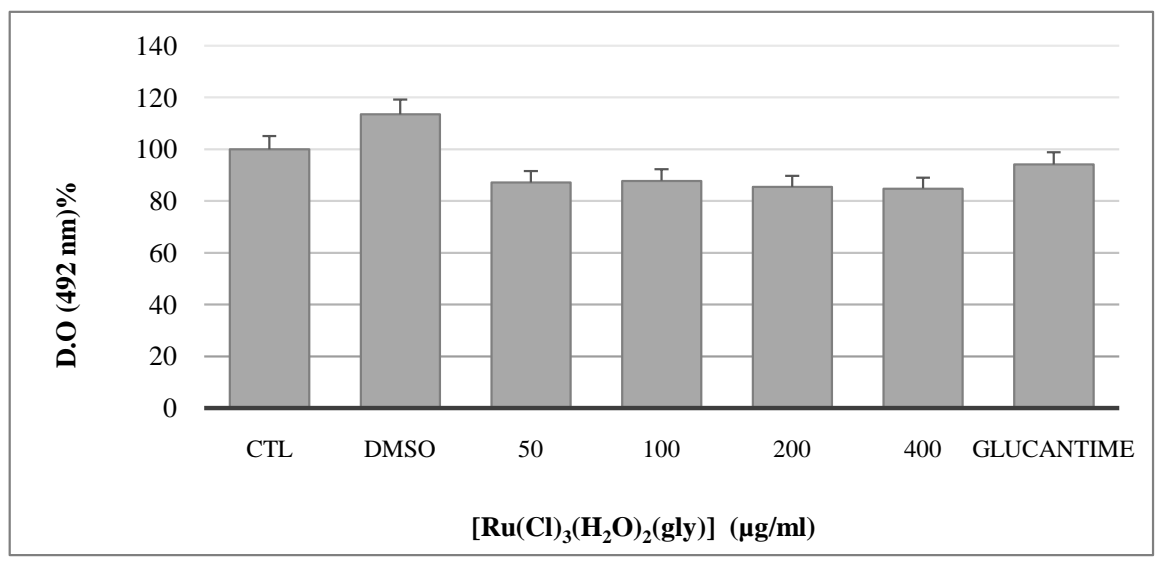

Figure 5. Effect of compound III Ruthenium and Ruthenium on cell viability of murine peritoneal macrophages. Cell viability was determined by MTT test. Peritoneal macrophages of mice were exposed for 24 hours to the compounds III and Ruthenium $\mathrm{Ru}$ in different concentrations. As a positive control was used Glucantime ${ }^{\circledast}$ in the concentration of $300 \mu \mathrm{g} / \mathrm{mL}$. After $4 \mathrm{~h}$ incubation with MTT, this was removed and added DMSO. As a negative control was used only RPMI culture. The absorbance was measured at $492 \mathrm{~nm}$. $100 \%$ viability corresponds to determined viability for the negative control. Results are expressed as mean \pm DP. Results Ruthenium ( $n=7$, each experiment being in five replications). ${ }^{\star}$ Significant difference from the negative control when $\mathrm{p}<0.05 ;{ }^{* *} \mathrm{p}<0.01$.

When cultures of macrophages were infected by the parasite L. Amazonensis and treated with $50 \mu \mathrm{g} / \mathrm{mL}$ of the compound, there were no changes in the percentage of infection when compared to control. In contrast, treatment with concentrations of 100 and $400 \mu \mathrm{g} / \mathrm{mL}$ was able to reduce the infection of macrophages by $31 \%$ at both doses examined. Similarly, a $49 \%$ reduction in the per- 
centage of infected cells was found when macrophages were treated with 400 $\mu \mathrm{g} / \mathrm{mL}\left[\mathrm{Ru}(\mathrm{Cl})_{3}\left(\mathrm{H}_{2} \mathrm{O}\right)_{2}(\mathrm{gly})\right]$ compound (Figure $6(\mathrm{a})$ ). The parasite load was evaluated using the number of parasites per cell. The control conditions showed a parasitic load of 2.0 amastigotes per cell (Figure 6(b)). When macrophages were treated with the compound at a range of concentrations of $200 \mathrm{mg} / \mathrm{mL}$ to $400 \mathrm{mg} / \mathrm{mL}$, the number of parasites per cell fell from 1.5 to about 3 per cell (Figure 6(b)).

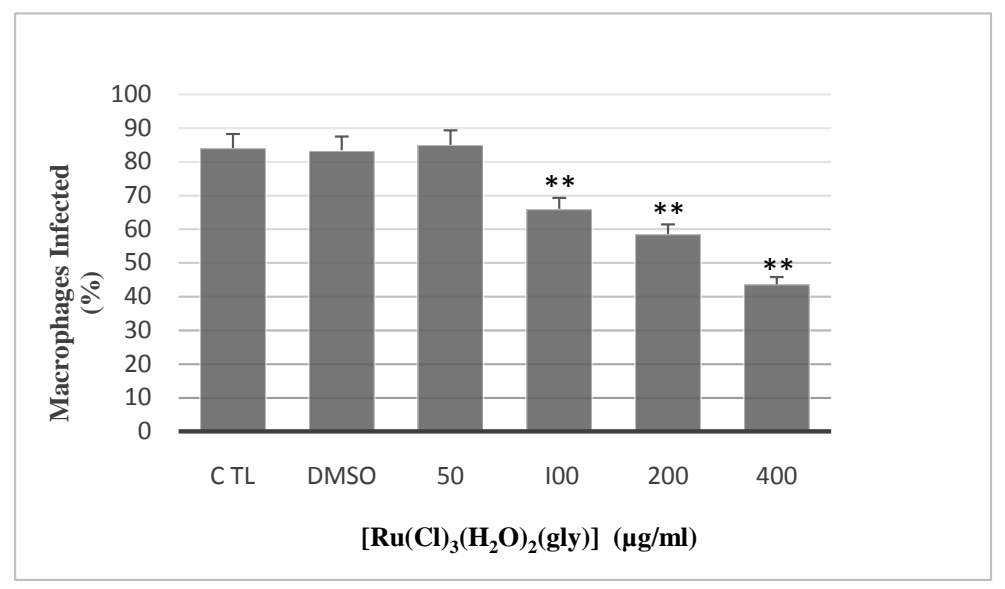

(a)

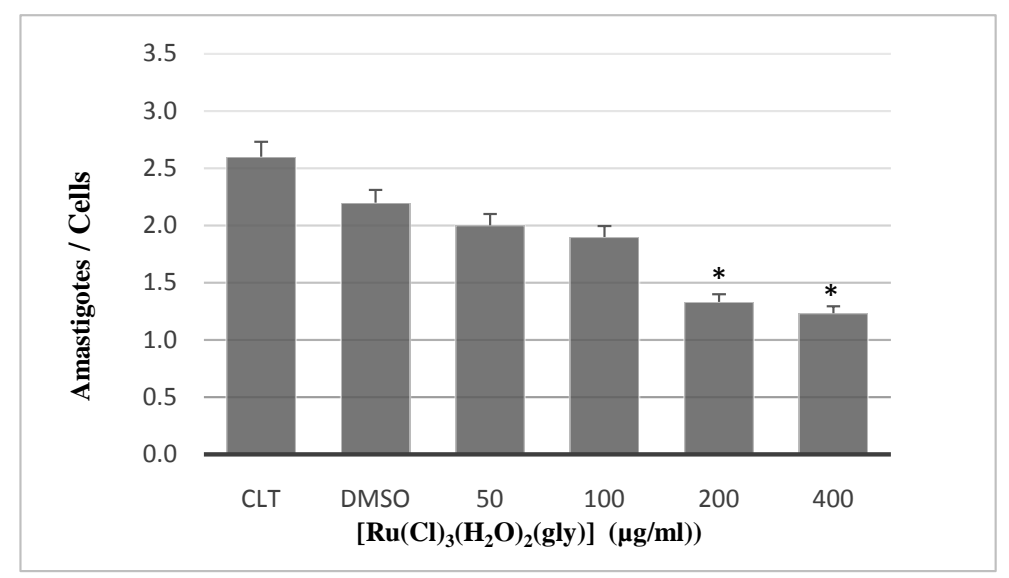

(b)

Figure 6. Effect of compound Ruthenium in murine peritoneal macrophages infected with L. amazonensis amastigotes. Peritoneal macrophages of mice were incubated for $1 \mathrm{~h}$ with L. amazonensis amastigotes in the ratio 5:1 then exposed for $24 \mathrm{~h}$ at $37^{\circ} \mathrm{C}$ and $5 \%$ $\mathrm{CO}_{2}$ to ruthenium at the indicated concentrations. As a negative control were used macrophages withdrawn from the peritoneum of Balb/c only grown in culture medium RPMI 1640 and control treated with DMSO at $0.1 \%$. (a) The average number of infected macrophages adhered to the glass coverslips treated with $(50 \mu \mathrm{g} / \mathrm{mL}$ to $400 \mu \mathrm{g} / \mathrm{mL})$ and stained with Giemsa, was obtained by counting by optical microscopy. The values obtained by the average percentage of infected macrophages in independent events made in triplicate; (b) Average number of amastigotes determined in cultured macrophages when exposed to ruthenium treatment for $24 \mathrm{~h}$ with the indicated concentrations and counted MO. The result is Mean \pm DP in triplicate. The significance of the difference among treatment is indicated in the figure $\left({ }^{*} \mathrm{p} \leq 0.05 ;{ }^{* *} \mathrm{p} \leq 0.01\right)$. 
To investigate the effects of isolated glycine ligand, macrophages were treated with different doses of the ligand in a concentration range of $100 \mathrm{mg} / \mathrm{mL}$ to 750 $\mathrm{mg} / \mathrm{mL}$. When glycine doses below $500 \mathrm{mg} / \mathrm{mL}$ were used there were no significant changes in the percentage of infection, as compared to the control (Figure 7 (a)). Under the same experimental conditions, a dose of $750 \mathrm{mg} / \mathrm{mL}$ glycine reduced the percentage of infected macrophages by $44 \%$ (Figure $7(\mathrm{~b})$ ).

\section{Conclusion}

Thermal analysis allowed the determination of the stoichiometry of the ruthe-

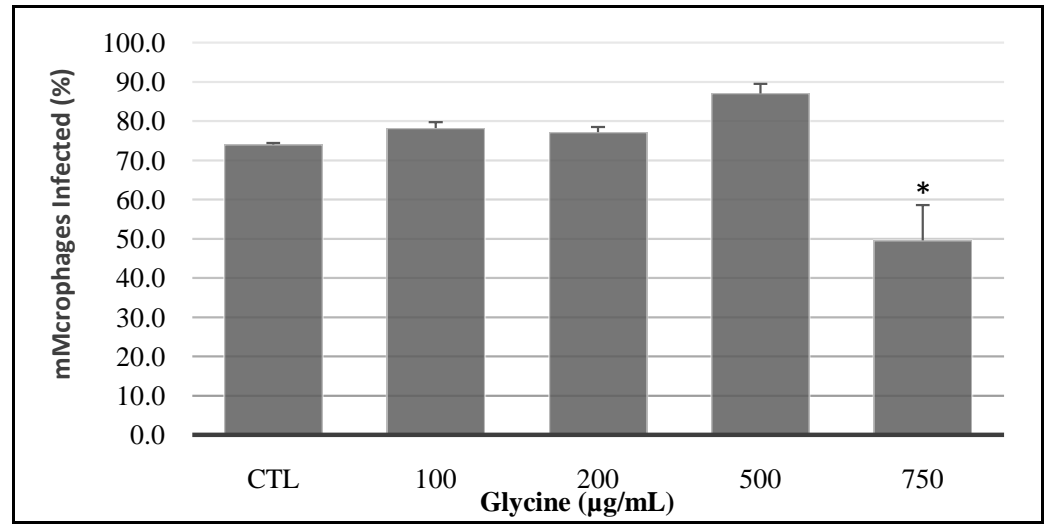

(a)

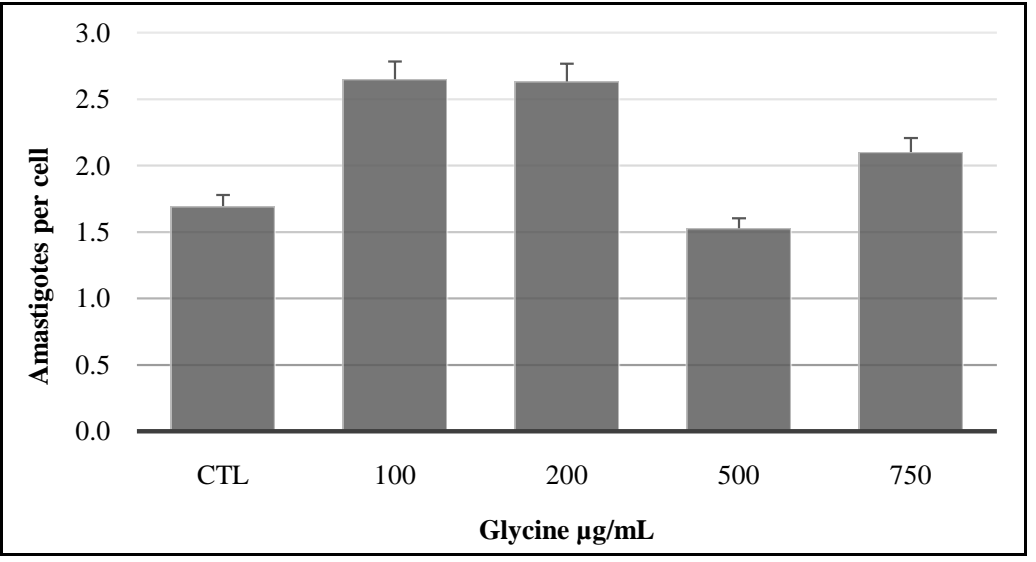

(b)

Figure 7. Effect of Glycine in murine peritoneal macrophages infected with L. amazonensis amastigotes. Macrophages were incubated for $1 \mathrm{~h}$ with L. amazonensis amastigotes in the ratio 5: 1 , and then exposed for $24 \mathrm{~h}$ at $37^{\circ} \mathrm{C}$ and $5 \% \mathrm{CO}_{2}$ glycine at the indicated concentrations. As a negative control were used peritoneal macrophages removed from $\mathrm{BALB} / \mathrm{c}$ mice cultured alone in RPMI 1640 culture medium (a) The number of infected macrophages adhered to the glass coverslips treated with glycine $(100 \mu \mathrm{g} \mathrm{mL}$ to 750 $\mu \mathrm{g} / \mathrm{ml}$ ) and stained with Giemsa, they were obtained by counting by optical microscopy. The values obtained by the average percentage of infected macrophages in independent events done in quadruplicate; (b) Average number of amastigotes determined in cultured macrophages when exposed to treatment with glycine for $24 \mathrm{~h}$ and counted at the indicated concentrations to MO. The result is Mean $\pm \mathrm{DP}$ in triplicate. The significance of the difference among treatment is indicated in the figure $\left({ }^{*} \mathrm{p} \leq 0.05 ;{ }^{* *} \mathrm{p} \leq 0.01\right)$. 
nium-glycine compound $\left[\mathrm{Ru}(\mathrm{Cl})_{3}\left(\mathrm{H}_{2} \mathrm{O}\right)_{2}(\right.$ gly $\left.)\right]$, however, it cannot determine the correct isomerism compound. With the analysis of the compound in the infrared region, it was possible to determine the shape of connection between the glycine ligand and metal ruthenium. It is observed that the glycine carboxylate group coordinated to the metal by only one of the oxygens, monodentate connection, thus assisting the determination of the formulation observed on thermal analysis. Spectroscopy in the UV-visible region reveals that the compound exhibits charge transfer processes LMCT between the metal and the ligand glycine. Treatment of cells infected with $L$. Amazonensis with the compound at concentrations of 100 and $400 \mu \mathrm{g} / \mathrm{mL}$ was able to reduce the infection of macrophages by $31 \%$. The parasitic burden, evaluated by the number of parasites per cell, also showed a $50 \%$ decrease when macrophages were treated with the compound at concentrations of $200 \mu \mathrm{g} / \mathrm{mL}$ to $400 \mu \mathrm{g} / \mathrm{mL}$.

\section{Acknowledgements}

Mato Grosso research support foundation (FAPEMAT), Federal University of Mato Grosso (UFMT).

\section{References}

[1] Sadler, P.J. (1991) Inorganic Chemistry and Drug Design. In: Sykes, A.G., Ed., Advances in Inorganic Chemistry, Academic Press, 36, 1-48.

https://doi.org/10.1016/S0898-8838(08)60035-5

[2] Laila, H., Abdel Rahman, R.M., El-Khatib, L.A., Nassr, E. and Abu-Dief, A.M. (2013) Design, Characterization, Teratogenicity Testing, Antibacterial, Antifungal and DNA Interaction of Few High Spin Fe (II) Schiff Base Amino Acid Complexes. Spectrochimica Acta Part A: Molecular and Biomolecular Spectroscopy, 111, 266-276. https://doi.org/10.1016/j.saa.2013.03.061

[3] Laila, H., Abdel Rahman, Ahmed, M., Abu-Dief, Ismael, M., Mohamed, M.A.A. and Hashem, N.A. (2016) Synthesis, Structure Elucidation, Biological Screening, Molecular Modeling and DNA Binding of Some Cu (II) Chelates Incorporating Imines Derived from Amino Acids. Journal of Molecular Structure, 1103, 233-244.

[4] Katsaros, N. and Anagnostopoulou, A. (2002) Rhodium and Its Compounds as Potential Agents in Cancer Treatment. Critical Reviews in Oncology/Hematology, 42, 297-308. https://doi.org/10.1016/S1040-8428(01)00222-0

[5] Paula, W., Sinisterra, R., Santos, R. and Beraldo, H. (2005) A QuímicaInorgânica no planejamento de fármacosusados no controle da hipertensão [Inorganic Chemistry in the Planning of Drugs Used to Control Hypertension]. Cadernos Temáticos de Química Nova na Escola, 6, 19-23.

[6] Waxman, S. and Anderson, K.C. (2001) History of the Development of Arsenic Derivatives in Cancer Therapy. The Oncologist, 6, 3-10.

https://doi.org/10.1634/theoncologist.6-suppl 2-3

[7] Gallori, E., Vettori, C., Alessio, E., Vilchez, F.G., Vilaplana, R., Orioli, P., Casini, A. and Messori, L. (2000) DNA as a Possible Target for Antitumor Ruthenium(III) Complexes. Archives of Biochemistry and Biophysics, 376, 156-162. https://doi.org/10.1006/abbi.1999.1654

[8] Clarke, M.J. (2003) Ruthenium Metallopharmaceuticals. Coordination Chemistry 
Reviews, 236, 209-233. https://doi.org/10.1016/S0010-8545(02)00312-0

[9] Suriano, G., Yew, S., Ferreira, P., Senz, J., Kaurah, P., Ford, J. M. and Oliveira, M.J (2005) Characterization of a Recurrent Germ Line Mutation of the E-Cadherin Gene: Implications for Genetic Testing and Clinical Management. Clinical Cancer Research, 11, 5401-5409. https://doi.org/10.1158/1078-0432.CCR-05-0247

[10] Clarke, M.J., Buchbinder, M. and Kelman, A.D. (1978) Binding of Pentaammineruthenium(III) to Double-Helical and Single-Stranded DNA. Inorganica Chimica Acta, 27, L87-L88. https://doi.org/10.1016/S0020-1693(00)87238-2

[11] Gupta, G., Gloria, S., Nongbri, S.L., Therrien, B. and Rao, K.M. (2011) Study of Complexes of Platinum Group Metals Containing Nitrogen Bases Derived from Pyridine Aldehydes: Interesting Molecular Structures with Unpredicted Bonding Modes of the Ligands. Journal of Organometallic Chemistry, 696, 2014-2022.

[12] De Castro, P.F., de Lima, A.P., Vilanova-Costa, C.A.S.T., Pires, W.C., Ribeiro, A.D.S.B.B., Pereira, L.C.G., Pavanin, L.A., Santos, W.B. and de Paula Silveira-Lacerda, E. (2014) Cytotoxic Effects of the Compound Cis-Tetraammine (oxalato)ruthenium(III) Dithionate on K-562 Human Chronic Myelogenous Leukemia Cells. Springer Plus, 3, 301-310.

[13] Vilanova-Costa, C.A.S.T., Porto, H.K.P., Pereira, F.D.C., de Lima, P.A., Santos, B.W. and Silveira-Lacerda, E.P. (2014) The Ruthenium Complexes Cis-(dichloro) Tetramineruthenium(III) Chloride and Cis-Tetraammine(oxalato)ruthenium(III) Dithionate Overcome Resistance Inducing Apoptosis on Human Lung Carcinoma Cells (A549). BioMetals, 27, 459-469. https://doi.org/10.1007/s10534-014-9715-X

[14] Vilanova-Costa, C.A.S.T., Porto, H.K.P., Pereira, L.C.G., Carvalho, B.P., Santos, W.B. and Silveira-Lacerda, E.P. (2015) MDR1 and Cytochrome P450 Gene-Expression Profiles as Markers of Chemosensitivity in Human Chronic Myelogenous Leukemia Cells Treated with Cisplatin and Ru(III) Metallocomplexes. Biological Trace Element Research, 163, 39-47. https://doi.org/10.1007/s12011-014-0133-2

[15] Arrais-Silva, W.W., Pinto, E.F., Rossi-Bergmann, B. and Giorgio, S. (2006) Hyperbaric Oxygen Therapy Reduces the Size of Leishmaniaamazonensis-Induced Soft Tissue Lesions in Mice. Acta Tropica, 98, 130-136.

[16] Navarro, M., Oscar, A.C.S., Colmenares, I. and Marchan, E. (2006) Ruthenium Polypyridyl Complexes: Synthesis, Characterization and Biological Activity on Leishmania (L) Mexicana. Letters in Drug Design \& Discovery, 3, 454-458. https://doi.org/10.2174/157018006778194826

[17] Barbiéri, C.L., Giorgio, S., Merjan, A. and Figueiredo, E.N. (1993) Glycosphingolipid Antigens of Leishmania (Leishmania) Amazonensisamastigotes Identified by Use of a Monoclonal Antibody. Infection and Immunity, 61, 2131-2137.

[18] Giorgio, S., Linares, E., Ischiropoulos, H., Von Zuben, F.J., Yamada, A. and Augusto, O. (1998) In Vivo Formation of Electron Paramagnetic Resonance-Detectable Nitric Oxide and of Nitrotyrosine Is Not Impaired during Murine Leishmaniasis. Infection and Immunity, 66, 807-814.

[19] Colhone, M.C., Arrais-Silva, W.W., Picoli, C. and Giorgio, S. (2004) Effect of Hypoxia on Macrophage Infection by Leishmania Amazonensis. Journal of Parasitology, 90, 510-515. https://doi.org/10.1645/GE-3286

[20] Degrossoli, A. and Giorgio, S. (2007) Functional Alterations in Macrophages after Hypoxia Selection. Experimental Biology and Medicine, 232, 88-95.

[21] Chang, K. (1980) Human Cutaneous Lieshmania in a Mouse Macrophage Line: Propagation and Isolation of Intracellular Parasites. Science, 209, 1240-1242. 
https://doi.org/10.1126/science.7403880

[22] Linares, E., Augusto, O., Barão, S.C. and Giorgio, S. (2000) Leishmaniaamazonensis Infection Does Not Inhibit Systemic Nitric Oxide Levels Elicited by Lipopolysaccharide in Vivo. Journal of Parasitology, 86, 78-82. https://doi.org/10.1645/0022-3395(2000)086[0078:LAIDNI]2.0.CO;2

[23] Ayres, M., Ayres, J.R.M., Ayres, D. and Santos, A. (2007) BioEstat 5.3: Aplicações Estatísticasnas Áreas das Ciências Biológicas e Médicas. Belém-PA Publicações Avulsas do Mamirauá. [Statistical Applications in the Areas of Biological and Medical Sciences.]

[24] Yeh, A. and Taube, H. (1980) Acid Hydrolysis of Ethyl Glycinate Complex of Pentaammineruthenium(III). Journal of the American Chemical Society, 102, 4725-4729. https://doi.org/10.1021/ja00534a028

[25] Bento, M.L. and Tfouni, E. (1988) Spectra, Reduction Potentials, and Coordinated Pyrazinebasicities in the Ruthenium(II) Complexes Trans-Ru(NH3)4LL'n+1. Inorganic Chemistry, 27, 3410-3413. https://doi.org/10.1021/ic00292a028

[26] Kitamura, Y., Takenaka, N., Koyano, Y. and Nagaoka, M. (2014) Dual Approach to Vibrational Spectra in Solution: Microscopic Influence of Hydrogen Bonding to the State of Motion of Glycine in Water. Journal of Chemical Theory Computation, 10 , 3369-3379. https://doi.org/10.1021/ct500235a

[27] Nakamoto, K. (1978) Infrared and Raman Spectra of Inorganic and Coordination Compounds.

[28] Kohata, S., Sagara, K., Takada, H. and Ohyoshi, A. (1985) Thermal Reaction of Aquaammineruthenium(III) Complex with Amino Acid or Imidazole Derivative in the Solid State. Polyhedron, 4, 1059-1066. 